W.

\title{
Derivation of Uranium Residual Radioactive Material Guidelines for the 4400. Piehl Road Site, Ottawa Lake, Michigan
}

by E. Faillace, M. Nimmagadda, and C. Yu

Environmental Assessment Division,

Argonne National Laboratory, 9700 South Cass Avenue, Argonne, Illinois 60439

December 1994

Work sponsored by United States Department of Energy, Office of Environmental Restoration, Washington, D.C.

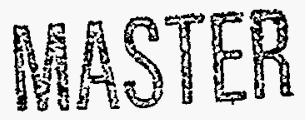


This report is printed on recycled paper. 


\section{DISCLAIMER}

This report was prepared as an account of work sponsored by an agency of the United States Government. Neither the United States Government nor any agency thereof, nor any of their employees, make any warranty, express or implied, or assumes any legal liability or responsibility for the accuracy, completeness, or usefulness of any information, apparatus, product, or process disclosed, or represents that its use would not infringe privately owned rights. Reference herein to any specific commercial product, process, or service by trade name, trademark, manufacturer, or otherwise does not necessarily constitute or imply its endorsement, recommendation, or favoring by the United States Government or any agency thereof. The views and opinions of authors expressed herein do not necessarily state or reflect those of the United States Government or any agency thereof. 


\section{DISCLAIMER}

Portions of this document may be illegible in electronic image products. Images are produced from the best available original document. 


\section{CONTENTS}

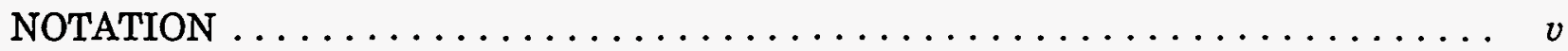

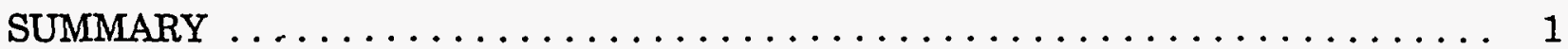

1 INTRODUCTION AND BRIEF HISTORY $\ldots \ldots \ldots \ldots \ldots \ldots \ldots \ldots$

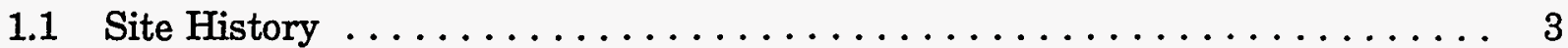

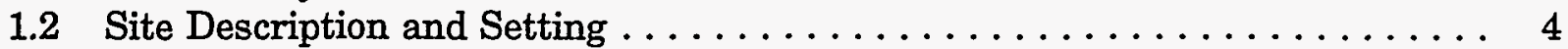

1.3 Derivation of Cleanup Guidelines $\ldots \ldots \ldots \ldots \ldots \ldots \ldots \ldots \ldots \ldots$

2 SCENARIO DEFINITIONS $\ldots \ldots \ldots \ldots \ldots \ldots \ldots \ldots \ldots \ldots$

3 DOSE/SOURCE CONCENTRATION RATIOS $\ldots \ldots \ldots \ldots \ldots \ldots \ldots \ldots$

4 RESIDUAL RADIOACTIVE MATERIAL GUIDELINES . . . . . . . . . . . . . . . 14

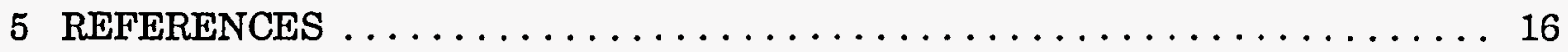

APPENDIX: Scenarios and Parameters Used for Analysis

of the 4400 Piehl Road Site . . . . . . . . . . . . . . . 17

\section{FIGURES}

1 Location of the 4400 Piehl Road Site, Ottawa Lake, Michigan . . . . . . . . . 4

2 Map of the 4400 Piehl Road Site, Ottawa Lake, Michigan . . . . . . . . . . . 5

\section{TABLES}

1 Summary of Exposure Pathways for Scenarios A and B at the 4400 Piehl Road Site $\ldots \ldots \ldots \ldots \ldots \ldots \ldots \ldots \ldots \ldots$

2 Maximum Dose/Source Concentration Ratios for Scenario A at the 4400 Piehl Road Site $\ldots \ldots \ldots \ldots \ldots \ldots \ldots \ldots \ldots \ldots \ldots \ldots \ldots$

3 Maximum Dose/Source Concentration Ratios for Scenario B at the 4400 Piehl Road Site . . . . . . . . . . . . . . . . . . . . . . . . 12

4 Total Dose/Source Concentration Ratios for Uranium at the 4400 Piehl Road Site . . . . . . . . . . . . . . . . . . . . 13

5 Residual Radioactive Material Guidelines for the 4400 Piehl Road Site . . . . . . 14 


\section{TABLES (Cont.)}

6 Ranges for Hot-Spot Multiplication Factors . . . . . . . . . . . . . . 15

A.1 Parameters Used in the RESRAD Computer Code for Analysis

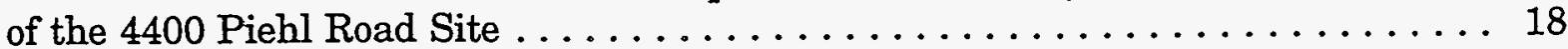




\section{NOTATION}

The following is a list of the acronyms, initialisms, abbreviations, and units of measure used in this document.

\section{ACRONYMS, INITIALISMS, AND ABBREVIATIONS}
AEC
U.S. Atomic Energy Commission
ALARA as low as reasonably achievable
DOE U.S. Department of Energy
FUSRAP Formerly Utilized Sites Remedial Action Program
$\mathrm{K}_{\mathrm{d}}$ uranium distribution coefficient
MAD Measurement Applications and Development
MED Manhattan Engineer District
ORNL Oak Ridge National Laboratory
RESRAD residual radioactive material guideline computer code

\section{UNITS OF MEASURE}

$\begin{array}{ll}\mathrm{cm} & \text { centimeter(s) } \\ \mathrm{cm}^{3} & \text { cubic centimeter(s) } \\ \mathrm{d} & \text { day(s) } \\ \mathrm{g} & \text { gram(s) } \\ \mathrm{h} & \text { hour(s) } \\ \mathrm{kg} & \text { kilogram(s) } \\ \mathrm{L} & \text { liter(s) } \\ \mathrm{m} & \text { meter(s) } \\ \mathrm{m}^{2} & \text { square meter(s) } \\ \mathrm{m}^{3} & \text { cubic meter(s) } \\ \mathrm{mrem} & \text { millirem(s) } \\ \mathrm{pCi} & \text { picocurie(s) } \\ \mathrm{s} & \text { second(s) } \\ \mathrm{yr} & \text { year(s) }\end{array}$




\title{
DERIVATION OF URANIUM RESIDUAL RADIOACTIVE MATERIAL GUIDELINES FOR THE 4400 PIEHL ROAD SITE, OTTAWA LAKE, MICHIGAN
}

by

\author{
E. Faillace, M. Nimmagadda, and C. Yu
}

\section{SUMMARY}

Residual radioactive material guidelines for uranium were derived for the 4400 Piehl Road site in Ottawa Lake, Michigan. This site has been designated for remedial action under the Formerly Utilized Sites Remedial Action Program (FUSRAP) of the U.S. Department of Energy (DOE). Single nuclide and total uranium guidelines were derived on the basis of the requirement that the 50-year committed effective dose equivalent to a hypothetical individual who lives or works in the immediate vicinity of the 4400 Piehl Road site should not exceed $30 \mathrm{mrem} / \mathrm{yr}$ following remedial action for the current use and plausible future use scenarios (Yu et al. 1993). The DOE residual radioactive material guideline computer code, RESRAD, which applies the methodology described in the DOE manual for implementing residual radioactive material guidelines, was used in this evaluation.

Two potential scenarios were considered in which it was assumed that, for a period of 1,000 years following remedial action, the site would be used without radiological restrictions. The two scenarios varied with regard to the type of site use and sources of food consumed. The results of the evaluation indicated that the basic dose constraint of $30 \mathrm{mrem} / \mathrm{yr}$ would not be exceeded for uranium (including uranium-234, uranium-235, and uranium-238) within 1,000 years, provided that the soil concentration of total combined uranium (uranium-234, uranium-235, and uranium-238) at the 4400 Piehl Road site did not exceed the following levels: $290 \mathrm{pCi} / \mathrm{g}$ for scenario A (residential: current use scenario) and $190 \mathrm{pCi} / \mathrm{g}$ for scenario $\mathrm{B}$ (subsistence farming: a plausible future use scenario).

The uranium guidelines derived in this analysis apply to the total activity concentration of uranium isotopes (i.e., uranium-238, uranium-234, and uranium-235) present in their natural activity concentration ratio of 1:1:0.046. Consequently, if uranium-238 were measured as the indicator radionuclide, the respective limits for scenarios $A$ and $B$ would be 140 and $91 \mathrm{pCi} / \mathrm{g}$, respectively. These guidelines were calculated on the basis of a dose of $30 \mathrm{mrem} / \mathrm{yr}$ for scenarios A and B (Yu et al. 1993). In setting the actual uranium guidelines for the 4400 Piehl Road site, DOE will apply the as low as reasonably achievable (ALARA) policy to the decision-making process, along with other factors, such as whether a particular scenario is reasonable and appropriate. 


\section{INTRODUCTION AND BRIEF HISTORY}

The 4400 Piehl Road site is located in Ottawa Lake, Michigan (Figure 1). The site has been designated by the U.S. Department of Energy (DOE) for remedial action under its Formerly Utilized Sites Remedial Action Program (FUSRAP). This designation was made after a radiological survey by Oak Ridge National Laboratory (ORNL) in September 1992 (Foley and Johnson 1993). The results of the radiological survey indicated that uranium contamination is present in two areas where materials were reportedly transported to the property from another FUSRAP site (the former Baker Brothers site in Toledo, Ohio). FUSRAP was established in 1974 by the U.S. Atomic Energy Commission (AEC), a predecessor of DOE. The mandate of the program is to identify, evaluate, and, if necessary, decontaminate sites previously used by the AEC or its predecessor, the Manhattan Engineer District (MED).

Remedial action activities at the 4400 Piehl Road site will follow the guidelines established in DOE Order 5400.5 (DOE 1990). The DOE residual radioactive material guideline computer code, RESRAD (Yu et al. 1993), derives residual radionuclide guidelines on a site-specific basis. This report presents the uranium guidelines derived for the 4400 Piehl Road site on the basis of a dose constraint of $30 \mathrm{mrem} / \mathrm{yr}$ for the current use and plausible future use scenarios (Yu et al. 1993). A dose limit of $100 \mathrm{mrem} / \mathrm{yr}$ has been used in deriving guidelines for unlikely yet plausible future use scenarios, but such scenarios are not considered in this report because the bounding future use scenario (subsistence farming) is not an improbable one in view of the extensive farmland in the vicinity of the site. The dose constraint of $30 \mathrm{mrem} / \mathrm{yr}$ is not currently required under DOE Order 5400.5 but is in the proposed 10 CFR Part 834 rulemaking to account for additional dose contributions from other potential sources of radiation exposure.

\subsection{SITE HISTORY}

During the early and mid-1940s, Baker Brothers, Inc., in Toledo, Ohio, fabricated uranium slugs from processed uranium metals under subcontract to the MED. This commercial property consisted of several buildings and grounds covered with either asphalt or concrete, except for a dirt courtyard at the northwestern end of the site. The Baker Brothers property was decontaminated at contract termination and later reevaluated under the DOE FUSRAP. Because the Baker Brothers uranium metal fabrication was related to AEC activities, a survey of existing conditions was performed to determine whether the site met current radiological guidelines. The principal radionuclide of concern was uranium-238. In June 1989, the preliminary radiological survey at the former Baker Brothers site (2551-2555 Harleau Place, Toledo, Ohio) was conducted by members of the Measurement Applications and Development (MAD) group of the ORNL at the request of DOE. Results of that survey indicated partial contamination with uranium-238. The Baker property was officially included in the FUSRAP program in late 1992 (Foley and Johnson 1993). 
The Baker Brothers' assets were liquidated, machinery and equipment were sold at auction, and the property was divided and sold to two independent companies. One part of the property was resold in the summer of 1992. The new owner contacted ORNL and inquired about the radiological status of his property. Through this conversation it was learned that soil and debris from the former Baker Brothers site may have been moved to the 4400 Piehl Road site in Ottawa Lake, Michigan.

\subsection{SITE DESCRIPTION AND SETTING}

The property at 4400 Piehl Road in Ottawa Lake, Michigan, is in a semi-rural area approximately $25 \mathrm{~km}$ northwest of Toledo, Ohio (Figure 1). The general area of the property is flat and has a large number of trees. The site consists of approximately $28,300 \mathrm{~m}^{2}$ and includes one owner-occupied house, a barn, and a pond (Figure 2).

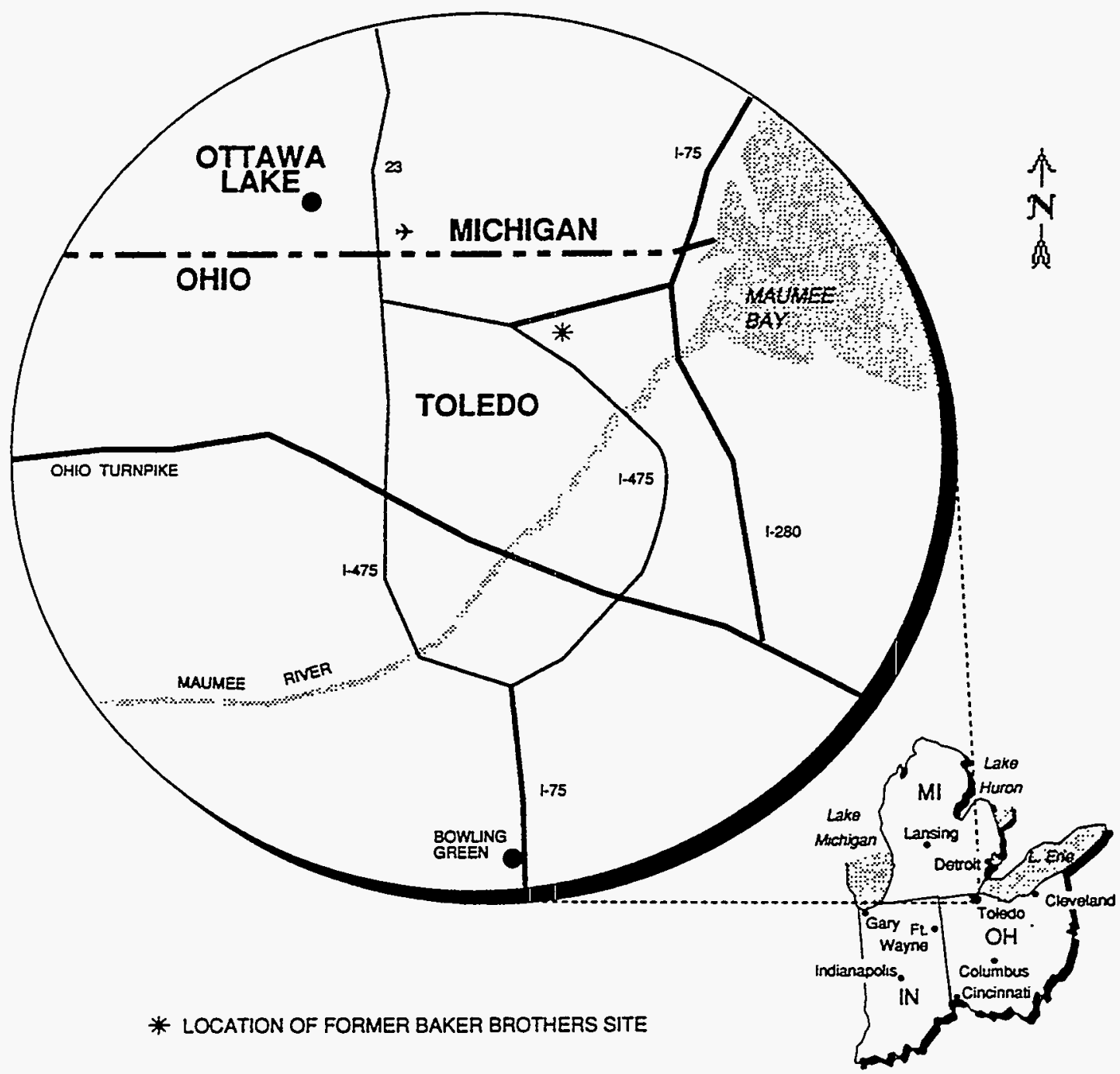

FIGURE 1 Location of the 4400 Piehl Road Site, Ottawa Lake, Michigan (Adapted from Foley and Johnson 1993) 


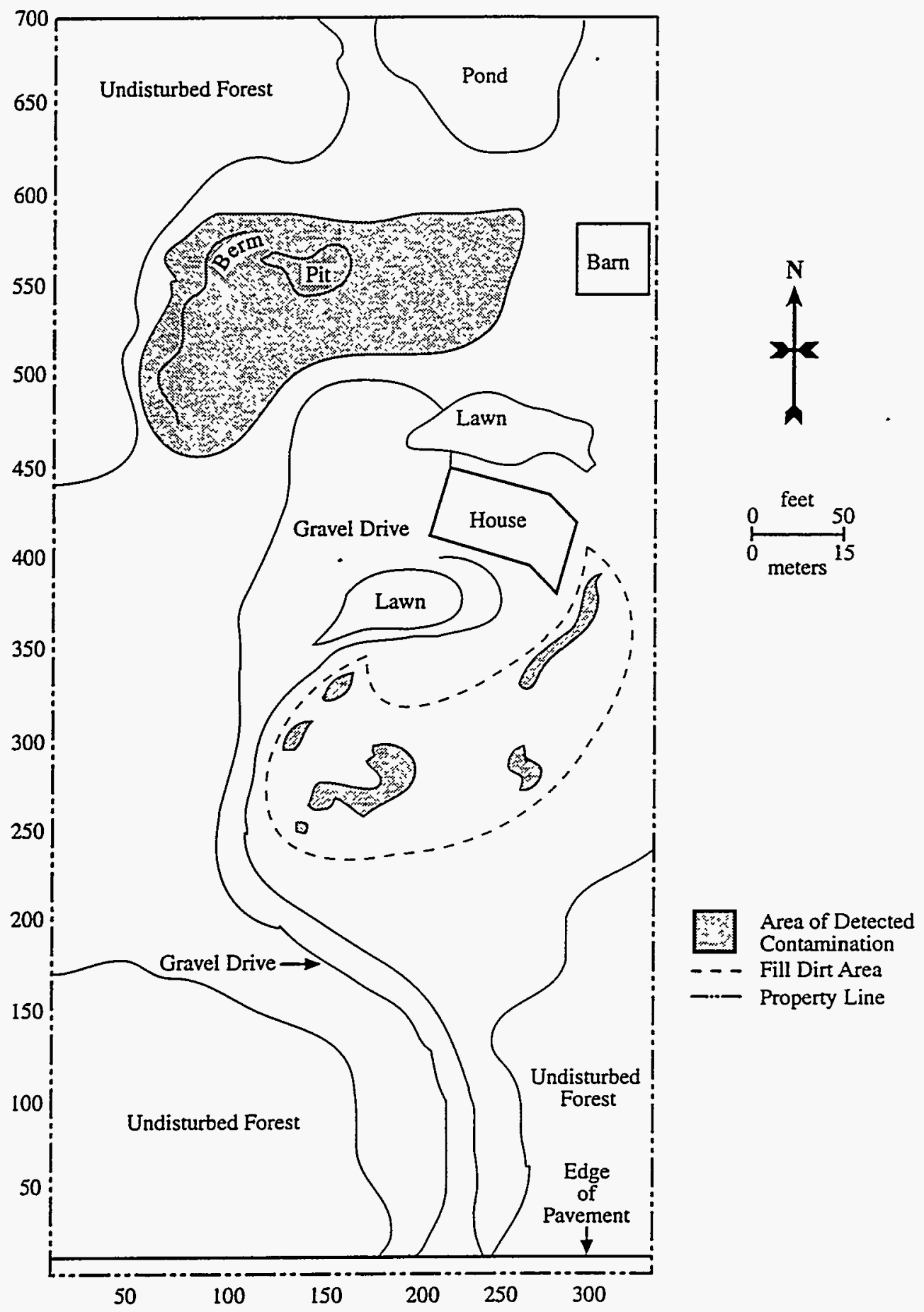

FIGURE 2 Map of the 4400 Piehl Road Site, Ottawa Lake, Michigan (Adapted from Foley and Johnson 1993) 
The owner states that several dozen large dump truck loads of soil, concrete, and tree stumps were transported to his property from the former Baker Brothers site and were placed either in front of his house or in a large pile behind and approximately $30 \mathrm{~m}$ northwest of the house. The owner also states that a large pit approximately $3 \mathrm{~m}$ deep was dug at the edge of the pile. The tree stumps and the concrete slabs from the former Baker Brothers site were reportedly dumped into the pit, covered with additional soil, and leveled. The pile and pit area is approximately $25-30 \mathrm{~m}$ from the pond (see Figure 2). Surface water drains from this area to the pond.

Because soil had reportedly been hauled to this site from the former Baker Brothers property in Toledo, Ohio, the MAD Group at ORNL conducted a radiological survey of the 4400 Piehl Road site at the request of the DOE on September 20-21, 1992. The transported soil, which was readily discernable from the native soil because of its color and texture, contained a large amount of ash, cinders, and sand. It also contained heavily rusted scrap metal, brick, and other debris that might be found at an industrial site. Radiological survey results indicated isolated spots of uranium contamination in surface and subsurface soil in two areas where materials from the former Baker Brothers site were reportedly placed. One contaminated area is a large "U"-shaped region (approximately $1,900 \mathrm{~m}^{2}$ ) located in front of (south) and east of the house at the edge of the existing lawn. The soil in this area has been leveled and spread and varies in depth from a few centimeters to about $60 \mathrm{~cm}$. About $10 \%$ of this area has detectable surface contamination, and there may be contamination that is not detectable by surface measurements under some of the "clean" surface soil. The second area of transported soil (approximately 2,100 $\mathrm{m}^{2}$ ) is northwest of the house and includes an "L"-shaped soil berm approximately $1.5-1.8 \mathrm{~m}$ high by $15 \mathrm{~m}$ long. The pit is located at the end of the eastern leg of the "L." Most of this second area has spotty contamination (Foley and Johnson 1993).

Concentrations of uranium-238 found in soil samples taken from the location of the elevated gamma measurements exceeded typical site-specific uranium guidelines for soil that were derived for similar DOE FUSRAP sites. These areas are located to the south, northwest, and southeast of the house (see areas labeled as contaminated on Figure 2). Sample analyses and field measurements indicated that the berm had the highest concentrations of uranium.

On the basis of weather records for Toledo, Ohio, located $25 \mathrm{~km}$ southeast of Ottawa Lake, the average annual precipitation at the 4400 Piehl Road site is estimated to be $81 \mathrm{~cm}$. The weather is characterized as humid, with average evapotranspiration. Irrigation, while not required to sustain vegetation, is assumed to be $20 \mathrm{~cm} / \mathrm{yr}$. The average dust loading is conservatively estimated to be $0.0001 \mathrm{~g} / \mathrm{m}^{3}$.

The natural surface soil consists of approximately $15 \mathrm{~cm}$ of topsoil followed by sandy layers. The measured uranium distribution coefficient $\left(\mathrm{K}_{\mathrm{d}}\right)$ in this soil ranges from 200 to $650 \mathrm{~cm}^{3} / \mathrm{g}$ when ambient (pore space) water is used (Orlandini 1994). Additional analyses using pond water from the property indicated a uranium $\mathrm{K}_{\mathrm{d}}$ value of $54 \mathrm{~cm}^{3} / \mathrm{g}$ (Orlandini 1994). While this $K_{d}$ value is below the range reported above, it is not representative of 
ambient conditions. A uranium $\mathrm{K}_{d}$ value of $200 \mathrm{~cm}^{3} / \mathrm{g}$ was used in the calculations because it is more representative of site conditions. Because the maximum dose is predicted to occur at time zero even when using a $\mathrm{K}_{\mathrm{d}}$ value of $54 \mathrm{~cm}^{3} / \mathrm{g}$, use of the latter would not affect the derivation of the soil guidelines.

The current residents of 4400 Piehl Road obtain their drinking and household water from a 40-m-deep well. The water level in this well is approximately $34 \mathrm{~m}$ below the ground surface (John 1994). The soil under the contaminated areas in the vicinity of the pond was found to be saturated at a depth of less than $1 \mathrm{~m}$; this condition may provide a pathway for radionuclides to migrate from the contaminated areas to the pond. Because of the present use of a deep well, the use of pond water is not considered a plausible drinking water exposure pathway, but was only assessed with respect to the consumption of fish caught in the pond and the potential use of pond water for irrigation and watering of livestock.

\subsection{DERIVATION OF CLEANUP GUIDELINES}

Although most DOE cleanup guidelines applicable to remedial actions at FUSRAP sites are generic (DOE 1990), guidelines for uranium are derived on a site-specific basis. The purpose of this analysis was to derive the residual radioactive material guidelines for uranium (i.e., uranium-234, uranium-235, uranium-238, and total uranium) that are applicable to remedial action at the 4400 Piehl Road site. The derived guidelines represent the residual concentration of uranium in a homogeneously contaminated area that must not be exceeded if the site is to be released for use without radiological restrictions. The total uranium guideline is derived by assuming that uranium-238, uranium-234, and uranium-235 are present in their natural activity concentration ratio of 1:1:0.046.

Site-specific uranium guidelines for the 4400 Piehl Road site were derived on the basis of a dose constraint of $30 \mathrm{mrem} / \mathrm{yr}$ for the current use and plausible future use scenarios (Yu et al. 1993); it was assumed that uranium is the only radionuclide present at an above-background concentration. The RESRAD computer code, version 5.191, was used to derive these guidelines. The RESRAD code applies the methodology described in the DOE manual for implementing residual radioactive material guidelines ( $Y u$ et al. 1993). 


\section{SCENARIO DEFINITIONS}

Two potential exposure scenarios were considered for the 4400 Piehl Road site. In these scenarios it was assumed that, at some time within 1,000 years, the site will be released for use without radiological restrictions following remedial action.

Scenario A (the current use scenario) assumed continued residential use of the site. Under this scenario, a hypothetical resident was assumed to spend $50 \%$ of the time indoors in the decontaminated area, $25 \%$ of the time outdoors in the decontaminated area, and $25 \%$ of the time away from the site. The resident was assumed to be exposed to external gamma radiation, to inhale dust and radon gas, and to ingest small amounts of soil originating from the decontaminated area. It was also assumed that the resident ingests fish caught in the existing pond, does not ingest any produce grown in the decontaminated area, and does not ingest meat or milk from livestock raised in the decontaminated area.

Scenario B (a plausible future use scenario) also assumed residential use of the site but included subsistence farming. This scenario is quite plausible because much of the surrounding area is cultivated and the property is large enough to sustain agricultural activities. In addition to the exposure pathways considered in scenario A, the resident was assumed to eat produce grown on the property and to ingest meat and milk from livestock fed with forage grown on-site. All water used by the resident for drinking, household purposes, irrigation, and watering of livestock was assumed to be drawn from the on-site well. As in scenario $A$, the resident was assumed to ingest fish from the on-site pond. The alternative use of the on-site pond for irrigation and watering of livestock was also investigated but did not alter the guideline values derived in the reference scenario. Because of the existence of a deep well, the use of pond water for drinking or household purposes was not considered realistic.

All exposure pathways considered for scenarios A and B are summarized in Table 1.

TABLE 1 Summary of Exposure Pathways for Scenarios A and $B$ at the 4400 Piehl Road Site

\begin{tabular}{lcc}
\hline \multicolumn{1}{c}{ Exposure Pathway } & Scenario A & \\
& Scenario B \\
\hline External exposure & Yes & Yes \\
Dust inhalation & Yes & Yes \\
Radon inhalation & Yes & Yes \\
Ingestion of produce grown on-site & No & Yes \\
Ingestion of meat from on-site livestock & No & Yes \\
Ingestion of milk from on-site livestock & No & Yes \\
Ingestion of fish from on-site pond & Yes & Yes \\
Ingestion of soil & Yes & Yes \\
Ingestion of water from on-site well & Yes & Yes \\
\hline \multirow{2}{*}{ a Resident (current use scenario). } & & \\
b Subsistence farmer (plausible future use scenario). &
\end{tabular}


The RESRAD computer code (Yu et al. 1993) calculated the potential radiation doses for the current and future residents on the basis of the following assumptions:

- During one year, the resident (both scenarios) spends 4,380 hours (50\%) indoors, 2,190 hours (25\%) outdoors in the decontaminated area, and 2,190 hours (25\%) away from the site.

- The walls, floor, and foundation of the house reduce external exposure by $30 \%$; the indoor dust level is $40 \%$ of the outdoor dust level (Yu et al. 1993).

- The airborne dust loading is $0.0001 \mathrm{~g} / \mathrm{m}^{3}$. This is a conservative estimate that takes into account short periods of high mass loading and sustained periods of normal activity typical of gardening or farming.

- The house depth below ground surface is $1 \mathrm{~m}$, with an effective radon diffusion coefficient of $3 \times 10^{-7} \mathrm{~m}^{2} / \mathrm{s}$.

- The size of the decontaminated area is sufficiently large that $50 \%$ of the produce consumed by the resident in scenario $B$ is grown in a garden in the decontaminated area. The resident in scenario $A$ does not consume produce grown on-site.

- The size of the decontaminated area is large enough to produce $20 \%$ of the forage used to feed livestock that produce meat and milk consumed by the resident in scenario B. The resident in scenario A does not consume on-site animal products.

- For both scenarios, $50 \%$ of the fish consumed by the resident is obtained from the on-site pond.

- The current supply of water is from a deep on-site well. For both scenarios $A$ and $B$, the source of water for drinking and household purposes is assumed to be from this well. In scenario $B$, this well water is also assumed to be used for irrigation and watering of livestock; assuming that pond water is used instead increases future doses but does not affect the maximum dose from all exposure pathways, which occurs immediately following decontamination.

- The uranium distribution coefficient is $200 \mathrm{~cm}^{3} / \mathrm{g}$ for all zones. Because of the lack of more site-specific data, the hydrological parameters used for the decontaminated area, the unsaturated zone, and the aquifer are conservative defaults for sand ( $\mathrm{Yu}$ et al. 1993).

- After remedial action, no cover material is placed over the decontaminated area. 
- For conservatism, no erosion of the contaminated material occurs.

- The average thickness of the contaminated zone is $1 \mathrm{~m}$. This value is a conservative estimate because in most parts of the contaminated area, the thickness was estimated from ORNL measurements to be less than $60 \mathrm{~cm}$ (Foley and Johnson 1993). However, in the pit area, contaminants may be present as deep as $3 \mathrm{~m}$ below the surface.

- The area of the contaminated zone is $4,000 \mathrm{~m}^{2}$. This value is the total for the two areas in which uranium contamination was detected above background levels. For modeling purposes, these two noncontiguous areas are conservatively treated as a single homogeneously contaminated zone of circular shape. 


\section{DOSE/SOURCE CONCENTRATION RATIOS}

The RESRAD computer code, version 5.191 (Yu et al. 1993), was used to calculate the dose/source concentration ratio $D S R_{i p}(t)$ for uranium isotope $i$ and pathway $p$ at time $t$ after remedial action. The time frame considered in this analysis was 1,000 years. Radioactive decay and ingrowth were considered in deriving the dose/source concentration ratios. The various parameters used in the RESRAD code for this analysis are listed in the Appendix. The calculated maximum dose/source concentration ratios for all exposure pathways are presented in Tables 2 and 3 for scenarios A and B, respectively. For both scenarios, the maximum dose/source concentration ratio occurs at time zero (immediately after remedial action). The primary pathways for scenario A are external exposure and dust inhalation; for scenario B, the dominant pathway is ingestion of produce grown in the decontaminated area.

The summation of $D S R_{i p}(t)$ for all pathways $p$ is the $D S R_{i}(t)$ for the $i$ th isotope:

$$
D S R_{i}(t)=\sum_{p} D S R_{i p}(t)
$$

The total dose/source concentration ratio for total uranium can be calculated as

$$
D S R(t)=\sum_{i} W_{i} D S R_{i}(t)
$$

where $W_{i}$ is the existing activity concentration fraction at the site for uranium-234, uranium-235, and uranium-238.

TABLE 2 Maximum Dose/Source Concentration Ratios for Scenario A (Resident) at the 4400 Piehl Road Site

\begin{tabular}{llll}
\hline & \multicolumn{3}{c}{$\begin{array}{c}\text { Maximum Dose/Source Concentration Ratios } \\
\text { Exposure Pathway }\end{array}$} \\
\cline { 2 - 4 } \multicolumn{1}{c}{ Exrem/yr)/(pCi/g) } \\
\cline { 2 - 4 } & Uranium-234 & Uranium-235 & Uranium-238 \\
\hline External exposure & $8.5 \times 10^{-4}$ & $5.5 \times 10^{-1}$ & $7.9 \times 10^{-2}$ \\
Dust inhalation & $4.7 \times 10^{-2}$ & $4.3 \times 10^{-2}$ & $4.3 \times 10^{-2}$ \\
Radon inhalation & 0 & 0 & 0 \\
Ingestion of fish from on-site pond & 0 & 0 & 0 \\
Ingestion of soil & $7.1 \times 10^{-3}$ & $6.8 \times 10^{-3}$ & $6.8 \times 10^{-3}$ \\
Ingestion of water from on-site well & 0 & 0 & 0 \\
\hline
\end{tabular}

a Maximum dose/source concentration ratios would occur immediately following remedial action; all values are reported to two significant figures. 
TABLE 3 Maximum Dose/Source Concentration Ratios for Scenario B (Subsistence Farmer) at the 4400 Piehl Road Site

\begin{tabular}{|c|c|c|c|}
\hline \multirow[b]{2}{*}{ Exposure Pathway } & \multicolumn{3}{|c|}{$\begin{array}{c}\text { Maximum Dose/Source Concentration Ratios }{ }^{\mathrm{a}} \\
(\mathrm{mrem} / \mathrm{yr}) /(\mathrm{pCi} / \mathrm{g})\end{array}$} \\
\hline & Uranium-234 & Uranium-235 & Uranium-238 \\
\hline External exposure & $8.5 \times 10^{-4}$ & $5.5 \times 10^{-1}$ & $7.9 \times 10^{-2}$ \\
\hline Dust inhalation & $4.7 \times 10^{-2}$ & $4.3 \times 10^{-2}$ & $4.3 \times 10^{-2}$ \\
\hline Radon inhalation & 0 & 0 & 0 \\
\hline Ingestion of produce grown on-site & $5.7 \times 10^{-2}$ & $5.4 \times 10^{-2}$ & $5.4 \times 10^{-2}$ \\
\hline Ingestion of meat from on-site livestock & $7.5 \times 10^{-4}$ & $7.2 \times 10^{-4}$ & $7.2 \times 10^{-4}$ \\
\hline Ingestion of milk from on-site livestock & $1.8 \times 10^{-3}$ & $1.8 \times 10^{-3}$ & $1.8 \times 10^{-3}$ \\
\hline Ingestion of fish from on-site pond & 0 & 0 & 0 \\
\hline Ingestion of soil & $7.1 \times 10^{-3}$ & $6.8 \times 10^{-3}$ & $6.8 \times 10^{-3}$ \\
\hline Ingestion of water from on-site well & 0 & 0 & 0 \\
\hline
\end{tabular}

a Maximum dose/source concentration ratios would occur immediately following remedial action; all values are reported to two significant figures.

For this analysis, $W_{i}$ was assumed to represent the natural activity concentration ratios of $1 / 2.046,1 / 2.046$, and $0.046 / 2.046$ for uranium-238, uranium-234, and uranium-235, respectively. The total dose/source concentration ratios for single nuclides and total uranium are provided in Table 4 . These ratios were used to determine the allowable residual radioactivity for uranium at the 4400 Piehl Road site.

Uncertainty in the derivation of dose/source concentration ratios arises from the distribution of possible input parameter values, as well as uncertainty in the conceptual model used to represent the site. Depending on the scenario, different parameters affect the results. For scenarios $\mathrm{A}$ and $\mathrm{B}$, the dust inhalation and external exposure pathways contributed significantly to the total dose. Therefore, uncertainty in parameters affecting these pathways, such as the thickness of the contaminated zone and mass loading of dust in the air, will affect the results more than parameters affecting other pathways. In addition, doses will depend strongly on the choice of occupancy factors selected for these two scenarios. Because the maximum dose occurred at time zero, uncertainties in parameters that affect the leaching of radionuclides from the contaminated zone (e.g., distribution coefficients) did not affect the results.

The RESRAD default values were used when no site-specific data were available. These default values are based on national average or reasonable maximum values. In addition, the contaminated zone thickness of $1 \mathrm{~m}$ selected to derive the dose/source concentration ratios was based on the assumption that the soil is uniformly contaminated to that depth. In reality, most of the contamination occurs in the top $60 \mathrm{~cm}$ of soil and is not dispersed uniformly throughout the site. Therefore, the calculated dose/source ratios are conservative. 
TABLE 4 Total Dose/Source Concentration Ratios for Uranium at the 4400 Piehl Road Site

\begin{tabular}{lll}
\hline & $\begin{array}{c}\text { Maximum Dose/Source } \\
\text { Concentration Ratios }\end{array}$ \\
& \multicolumn{2}{c}{$(\mathrm{mrem} / \mathrm{yr}) /(\mathrm{pCi} / \mathrm{g})$} \\
\cline { 2 - 3 } Radionuclide & Scenario A & Scenario B \\
\hline Uranium-234 & $5.5 \times 10^{-2}$ & $1.1 \times 10^{-1}$ \\
Uranium-235 & $6.0 \times 10^{-1}$ & $6.6 \times 10^{-1}$ \\
Uranium-238 & $1.3 \times 10^{-1}$ & $1.9 \times 10^{-1}$ \\
Total uranium & $1.0 \times 10^{-1}$ & $1.6 \times 10^{-1}$ \\
\hline
\end{tabular}

a All values are reported to two significant figures.

b Resident (current use scenario).

c Subsistence farmer (plausible future use scenario). 


\section{RESIDUAL RADIOACTIVE MATERIAL GUIDELINES}

The residual radioactive material guideline is the concentration of residual radioactive material that can remain in a decontaminated area and still allow use of the area without radiological restrictions. Given a dose constraint of $H_{E L}$ for an individual, the residual radioactive material guideline $G$ for uranium at the 4400 Piehl Road site can be calculated as

$$
G=H_{E L} / D S R,
$$

where $D S R$ is the total dose/source concentration ratio listed in Table 4. The dose constraint $H_{E L}$ used to derive the residual radioactive material guideline is $30 \mathrm{mrem} / \mathrm{yr}$ for the current use and plausible future use scenarios ( $\mathrm{Yu}$ et al. 1993). The calculated residual radioactive material guidelines for single radionuclides (uranium-234, uranium-235, and uranium-238) and total uranium are presented in Table 5.

In calculating the total uranium guidelines (reported to two significant figures), we assumed that the activity concentration ratio of uranium-238, uranium-234, and uranium-235 is 1:1:0.046. The derived guidelines for total uranium are 290 and $190 \mathrm{pCi} / \mathrm{g}$ for scenarios A and $B$, respectively. If uranium-238 is measured as the indicator radionuclide, the uranium-238 limits for total uranium can be calculated by dividing the total uranium guidelines by 2.046. The resulting uranium-238 limits are 140 and $91 \mathrm{pCi} / \mathrm{g}$ for scenarios A and $\mathrm{B}$, respectively.

TABLE 5 Residual Radioactive Material Guidelines for the $\mathbf{4 4 0 0}$ Piehl Road Site

\begin{tabular}{lcc}
\hline & \multicolumn{2}{c}{${\text { Guideline }(\mathrm{pCi} / \mathrm{g})^{\mathrm{a}}}^{\mathrm{a}}$} \\
\cline { 2 - 3 } Radionuclide & ${\text { Scenario } \mathrm{A}^{\mathrm{b}}}$ & Scenario B $^{\mathrm{c}}$ \\
\hline & & \\
Uranium-234 & 550 & 260 \\
Uranium-235 & 50 & 45 \\
Uranium-238 & 230 & 160 \\
Total uranium & 290 & 190 \\
\hline
\end{tabular}

a All values are reported to two significant figures.

b Resident (current use scenario: dose constraint $=30 \mathrm{mrem} / \mathrm{yr}$ ).

c Subsistence farmer (plausible future use scenario: dose constraint $=30 \mathrm{mrem} / \mathrm{yr}$ ). 
When the derived radionuclide guidelines for decontamination of a site are implemented, the law of sum of the fractions applies. That is, the summation of the radionuclide concentrations $S_{i}$ remaining on-site (averaged over an area of $100 \mathrm{~m}^{2}$ and a depth of $15 \mathrm{~cm}$ ) divided by their guidelines $G_{i}$ should not be greater than unity; that is,

$$
\sum_{i} S_{i} / G_{i} \leq 1
$$

The derived guidelines listed in Table 5 are for a large homogeneously contaminated area. For a small isolated area of contamination - a hot spot - the allowable concentration that can remain on-site may be higher than the homogeneous guideline, depending on the size of the contaminated area and in accordance with the ranges given in Table 6.

TABLE 6 Ranges for Hot-Spot Multiplication Factors

\begin{tabular}{cc}
\hline Range $\left(\mathrm{m}^{2}\right)$ & $\begin{array}{c}\text { Factor } \\
\text { (multiple of } \\
\text { authorized limit) }\end{array}$ \\
\hline$<1$ & $10^{\mathrm{a}}$ \\
$1-<3$ & 6 \\
$3-<10$ & 3 \\
$10-25$ & 2 \\
\hline a Areas $<1 \mathrm{~m}^{2}$ are averaged over a \\
$1-\mathrm{m}^{2}$ area; average shall not \\
exceed 10x authorized limit. \\
Source: Yu et al. (1993).
\end{tabular}




\section{REFERENCES}

Foley, R.D., and Johnson, C.A., 1993, Radiology Survey Results at 4400 Piehl Road, Ottawa Lake, Michigan (BTO002), ORNL/RASA-93/1, Oak Ridge National Laboratory, Oak Ridge, Tenn., April.

John, A.K, 1994, personal communication from John (Bechtel Environmental, Inc.) to E.R. Faillace (Argonne National Laboratory, Argonne, Ill.), Aug. 1.

Orlandini, K.A., 1994, unpublished information, Argonne National Laboratory, Argonne, $\mathrm{Ill}$.

U.S. Department of Energy (DOE), 1990, "Radiation Protection of the Public and Environment," U.S. Department of Energy Order 5400.5.

Yu, C., et al., 1993, Manual for Implementing Residual Radioactive Material Guidelines Using RESRAD, Version 5.0, ANL/EAD/LD-2, prepared by Argonne National Laboratory, Argonne, IIl., for U.S. Department of Energy, Office of Environmental Restoration, Washington, D.C., Sept. 


\section{APPENDIX: \\ SCENARIOS AND PARAMETERS USED FOR ANALYSIS \\ OF THE 4400 PIEHL ROAD SITE}

The following exposure scenarios were analyzed for the residence at 4400 Piehl Road in Ottawa Lake, Michigan:

- Scenario A: Residential Use of the Site - A hypothetical resident is assumed to live in the decontaminated area and to use an on-site well to supply water for drinking and household purposes. An on-site pond is present and provides fish; however, no produce is grown on-site, and no livestock is raised for the production of meat and mill.

- Scenario B: Subsistence Farming Use of the Site - A hypothetical resident is assumed to live in the decontaminated area and to use water from an on-site well for drinking, household purposes, watering of livestock, and irrigation. The resident is assumed to ingest produce grown in the garden and meat and milk from livestock fed with forage grown on-site. The resident is assumed to ingest fish from the on-site pond.

The parametric values used in the RESRAD code for the analysis of the residence at 4400 Piehl Road are listed in Table A.1. All parametric values are reported at up to three significant figures. Some parameters are specific to the Ottawa Lake site, others are generic. 
TABLE A.1 Parameters Used in the RESRAD Computer Code for Analysis of the 4400 Piehl Road Site

\begin{tabular}{|c|c|c|c|}
\hline \multirow[b]{2}{*}{ Parameter } & \multirow[b]{2}{*}{ Unit } & \multicolumn{2}{|c|}{ Value } \\
\hline & & Scenario A & Scenario B \\
\hline Area of contaminated zone $e^{a}$ & $\mathrm{~m}^{2}$ & 4,000 & 4,000 \\
\hline Thickness of contaminated zone $\mathrm{a}^{\mathrm{a}}$ & $\mathbf{m}$ & 1 & 1 \\
\hline Length parallel to aquifer flow ${ }^{a}$ & $\overline{\mathrm{m}}$ & 63 & 63 \\
\hline Basic radiation dose limit ${ }^{\mathrm{b}}$ & $\mathrm{mrem} / \mathrm{yr}$ & 30 & 30 \\
\hline Cover depth ${ }^{\mathrm{a}}$ & m & 0 & 0 \\
\hline \multicolumn{4}{|l|}{ Contaminated zone } \\
\hline Density b & $\mathrm{g} / \mathrm{cm}^{3}$ & 1.5 & 1.5 \\
\hline Erosion rate ${ }^{a}$ & $\mathrm{~m} / \mathrm{yr}$ & 0 & 0 \\
\hline Total porosity ${ }^{\mathrm{a}}$ & $-c$ & 0.4 & 0.4 \\
\hline Effective porosity ${ }^{\mathrm{a}}$ & $\mathbf{c}^{\mathrm{c}}$ & 0.3 & 0.3 \\
\hline Hydraulic conductivity ${ }^{\mathrm{a}}$ & $\mathrm{m} / \mathrm{yr}$ & 5,000 & 5,000 \\
\hline Soil-specific b parameter ${ }^{2}$ & $-c$ & 4.05 & 4.05 \\
\hline Evapotranspiration coefficient ${ }^{b}$ & $-c$ & 0.5 & 0.5 \\
\hline Precipitation $^{a}$ & $\mathrm{~m} / \mathrm{yr}$ & 0.81 & 0.81 \\
\hline Irrigation $^{b}$ & $\mathrm{~m} / \mathrm{yr}$ & 0.2 & 0.2 \\
\hline Irrigation mode ${ }^{b}$ & $-\mathrm{c}$ & Overhead & Overhead \\
\hline Runoff coefficient ${ }^{b}$ & c & 0.2 & 0.2 \\
\hline Watershed area for nearby pond ${ }^{b}$ & $\mathbf{m}^{2}$ & $1,000,000$ & $1,000,000$ \\
\hline Accuracy for water/soil computations ${ }^{b}$ &.$c$ & 0.001 & 0.001 \\
\hline \multicolumn{4}{|l|}{ Saturated zone } \\
\hline Density & $\mathrm{g} / \mathrm{cm}^{3}$ & 1.5 & 1.5 \\
\hline Total porosity ${ }^{\mathrm{a}}$ & -c & 0.4 & 0.4 \\
\hline Effective porosity ${ }^{2}$ & -c & 0.3 & 0.3 \\
\hline Hydraulic conductivitya & $\mathrm{m} / \mathrm{yr}$ & 5,000 & 5,000 \\
\hline Hydraulic gradient ${ }^{\mathrm{b}}$ & $-c^{-1}$ & 0.02 & 0.02 \\
\hline Water table drop rate ${ }^{a}$ & $\mathrm{~m} / \mathrm{yr}$ & 0 & 0 \\
\hline Well pump intake depth (below water table) ${ }^{\mathbf{a}}$ & $\mathrm{m}$ & 6 & 6 \\
\hline Model: nondispersion (ND) or mass balance (MB) & c & ND & ND \\
\hline Well pumping rate $\mathrm{b}^{\mathrm{b}}$ & $\mathrm{m}^{3} / \mathrm{yr}$ & 250 & 250 \\
\hline Number of unsaturated zone strata ${ }^{a}$ & c & 1 & 1 \\
\hline \multicolumn{4}{|l|}{ Unsaturated zone } \\
\hline Thickness $^{\mathrm{a}}$ & $\mathbf{m}$ & 33 & 33 \\
\hline Soil density ${ }^{\mathrm{b}}$ & $\mathrm{g} / \mathrm{cm}^{3}$ & 1.5 & 1.5 \\
\hline Total porosity ${ }^{\mathrm{a}}$ & c & 0.4 & 0.4 \\
\hline Effective porosity ${ }^{a}$ & $-c$ & 0.3 & 0.3 \\
\hline Soil-specific b parameter ${ }^{a}$ & $-c$ & 4.05 & 4.05 \\
\hline Hydraulic conductivity ${ }^{\mathrm{a}}$ & $\mathrm{m} / \mathrm{yr}$ & 5,000 & 5,000 \\
\hline Distribution coefficient $\mathrm{t}^{\mathrm{a}, \mathrm{b}}$ & $\mathrm{cm}^{3} / \mathrm{g}$ & & \\
\hline \multicolumn{4}{|l|}{ Contaminated zone } \\
\hline Uranium-234 & & 200 & 200 \\
\hline Uranium-235 & & 200 & 200 \\
\hline Uranium-238 & & 200 & 200 \\
\hline Actinium-227 ${ }^{\mathrm{e}}$ & & 20 & 20 \\
\hline Protactinium-231 & & 50 & 50 \\
\hline Lead-210 & & 100 & 100 \\
\hline Radium-226 & & 70 & 70 \\
\hline Thorium-230 & & 60,000 & 60,000 \\
\hline
\end{tabular}


TABLE A.1 (Cont.)

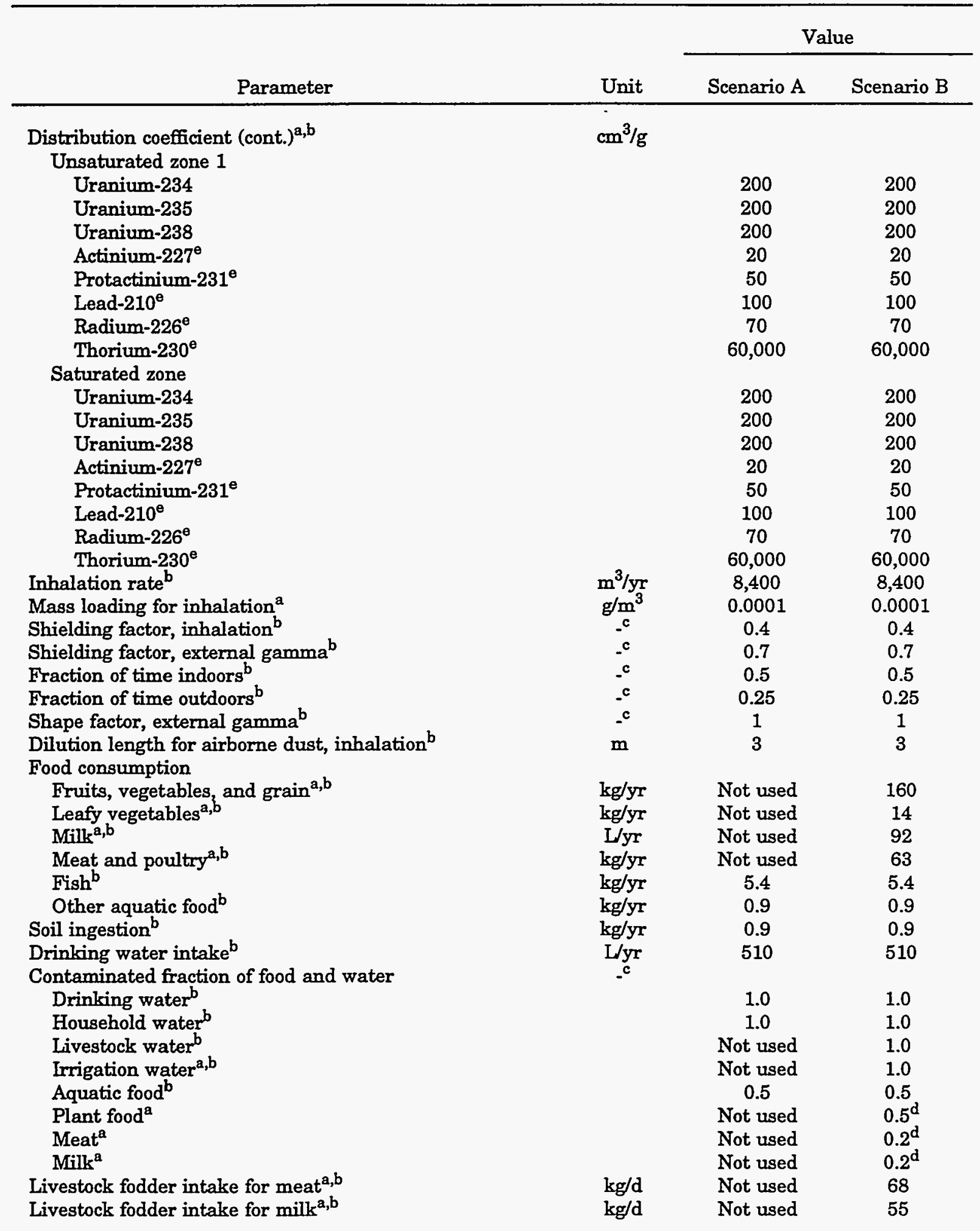


TABLE A.1 (Cont.)

\begin{tabular}{|c|c|c|c|}
\hline \multirow[b]{2}{*}{ Parameter } & \multirow[b]{2}{*}{ Unit } & \multicolumn{2}{|c|}{ Value } \\
\hline & & Scenario A & Scenario B \\
\hline Livestock water intake for milk ${ }^{a, b}$ & $\mathrm{~L} / \mathrm{d}$ & Not used & 160 \\
\hline Livestock soil intake $e^{\mathrm{a}, \mathrm{b}}$ & $\mathrm{kg} / \mathrm{d}$ & Not used & 0.5 \\
\hline Mass loading for foliar deposition ${ }^{\mathrm{a}, \mathrm{b}}$ & $\mathrm{g} / \mathrm{m}^{3}$ & Not used & 0.0001 \\
\hline Depth of soil mixing layer & $\mathrm{m}$ & 0.15 & 0.15 \\
\hline Depth of roots ${ }^{\mathbf{a}, \mathbf{b}}$ & $\mathrm{m}$ & Not used & 0.9 \\
\hline \multicolumn{4}{|l|}{ Groundwater fractional usage (balance from } \\
\hline Drinking water ${ }^{\mathrm{b}}$ & & 1.0 & 1.0 \\
\hline Household water ${ }^{b}$ & & 1.0 & 1.0 \\
\hline Livestock water ${ }^{a, b}$ & & Not used & 1.0 \\
\hline & & Not used & 1.0 \\
\hline \multicolumn{4}{|l|}{ Storage times of contaminated foodstuffs } \\
\hline Fruits, non-leafy vegetables, and grain ${ }^{\mathrm{a}, \mathrm{b}}$ & & Not used & 14 \\
\hline Leafy vegetables $\mathrm{a}^{\mathrm{a}, \mathrm{b}}$ & & Not used & 1 \\
\hline Milk & & Not used & 1 \\
\hline Meat and poultry ${ }^{\mathrm{a}, \mathrm{b}}$ & & Not used & 20 \\
\hline $\mathrm{Fish}^{\mathrm{a}, \mathrm{b}}$ & & 7 & 7 \\
\hline Crustacea and mollusks $\mathrm{s}^{\mathrm{a}, \mathrm{b}}$ & & 7 & 7 \\
\hline Well water $\mathbf{r}^{\mathrm{a}, \mathrm{b}}$ & & $i$ & 1 \\
\hline Livestock fodder ${ }^{a, b}$ & & Not used & 45 \\
\hline Volumetric water content of the foundation ${ }^{b}$ & $-^{c}$ & 0.03 & 0.03 \\
\hline \multicolumn{4}{|l|}{ Diffusion coefficient for radon gas } \\
\hline In foundation material ${ }^{b}$ & & $3.0 \times 10^{-7}$ & $3.0 \times 10^{-7}$ \\
\hline In contaminated zone soil ${ }^{b}$ & & $2.0 \times 10^{-6}$ & $2.0 \times 10^{-6}$ \\
\hline Emanating power of radon-222 &.$c$ & 0.25 & 0.25 \\
\hline Radon vertical dimension of mixing ${ }^{b}$ & $\mathbf{m}$ & 2.0 & 2.0 \\
\hline Average annual wind speed ${ }^{\mathrm{b}}$ & $\mathrm{m} / \mathrm{s}$ & 2.0 & 2.0 \\
\hline Average building air exchange rate ${ }^{\mathrm{b}}$ & $1 / \mathrm{h}$ & 0.5 & 0.5 \\
\hline Height of building (room) ${ }^{b}$ & $\mathbf{m}$ & 2.5 & 2.5 \\
\hline Building indoor area factor ${ }^{\mathrm{b}}$ & $c^{c}$ & 0 & 0 \\
\hline Bulk density of house or building foundation ${ }^{b}$ & $\mathrm{~g} / \mathrm{cm}^{3}$ & 2.4 & 2.4 \\
\hline Thickness of house or building foundation ${ }^{b}$ & $\mathbf{m}$ & 0.15 & 0.15 \\
\hline Building depth below ground surface ${ }^{\mathrm{b}}$ & $\mathrm{m}$ & 10 & 1.0 \\
\hline
\end{tabular}

a Values based on site specifications, scenario assumptions, or Manual for Implementing Residual Radioactive Material Guidelines Using RESRAD, Version 5.0, (C. Yu et al., 1993, report ANL/EAD/LD-2, prepared by Argonne National Laboratory, Argonne, Ill., for U.S. Department of Energy, Office of Environmental Restoration, Washington, D.C., Sept.).

b RESRAD default values.

c Parameter is dimensionless.

d Calculated with the RESRAD computer code.

e Radioactive progeny with half-lives $>6$ months. 